\title{
Space-time interaction in Hodgkin's disease in Greater Manchester
}

\author{
ABDULlaH MANGOUD*, VALERIE F HILliER, IAN LECK AND R W THOMAS
}

From the Department of Community Medicine and School of Geography, University of Manchester

SUMmARY Knox's test for space-time interaction was applied to 922 cases of Hodgkin's disease which, according to the North Western Regional Cancer Registry, had presented in 1962-76 among the population of the region known before 1974 as the South East Lancashire Conurbation. In the series as a whole, there were statistically significant excesses of pairs of patients separated by time intervals of less than a year and distances of less than $1 \mathrm{~km}$. Analysis by age and sex indicated that this clustering involved $(a)$ a trio of young females and $(b)$ pairs involving adults over 45 years old. No evidence was detected of any clustering by histological subtype or of any tendency for cases close in space to be separated by long time intervals of specific duration. These findings lend support to the idea that at least some cases of Hodgkin's disease may be induced by an infection or other environmental influence, but they do not suggest that such an infection has a long and specific incubation period.

Interest in the possible transmissibility of Hodgkin's disease (HD) was stimulated largely by Vianna et l $^{\mathbf{1}}$ and Vianna and Polan. ${ }^{2}$ Vianna et al described a group of 31 patients in Albany who had all been associated with a particular circle of friends at school. Vianna and Polan found that in Long Island schools where one case of HD had occurred, the subsequent incidence of HD was unusually high among both pupils and teachers. It was concluded that HD may be transmissible with both a variable incubation period and the involvement of asymptomatic carriers. There is, however, no guarantee that the case clusters found in these and similar anecdotal studies ${ }^{3}$ are not just chance interactions among a much larger series of random events. Smith and $\mathrm{Pike}^{4}$ have expressed this view arithmetically by suggesting that "if a new HD patient has had contact with 500 people in the preceding 10 years, then, by chance alone, about $20 \%$ of all HD patients might be expected to have contact with another person who develops HD in that period".

To date, statistical studies of the transmissibility hypothesis have yielded results that are inconclusive in comparison with those claimed from anecdotal evidence. Smith et $l^{5}$ found no evidence that patients in Oxford hospitals had more contact with each other before diagnosis than a matched set of controls admitted to hospital in the same year as the HD

*Present address: Department of Community Medicine and Primary Care, King Abdul Aziz University, Jeddah, Saudi Arabia. patients. In contrast, a case-control study of Jewish HD patients in Israel ${ }^{6}$ suggested that people living in certain parts of the country might have been exposed to certain environmental factors which enhanced the risk of HD. A recent editorial in The Lancet $^{7}$ summarises the controversy about the aetiology of HD by stating that "We are still uncertain as to the likelihood of its being an infectious disease, and since we have no agent we are in the same position as those classical epidemiologists who studied infectious diseases before the great discoveries of bacteriology".

The case for suspecting that an infective process is involved would be strengthened if space-time clustering among cases could be demonstrated. Such clustering could be of two kinds. Firstly, cases in persons who lived close together might be more likely than average to present at about the same time. Such a finding would suggest an infection that either had a short incubation period or that several people could acquire from the same source. Secondly, cases that were close in space might be more likely than average to present at approximately uniform time intervals, which would suggest an infection with a fairly constant incubation period.

An appropriate way to test for clustering of either type is to analyse all pairs of patients by the distances between their homes and the intervals between the dates when they presented, using Knox's ${ }^{8}$ test for space-time interaction. Alderson and Nayak $^{910}$ 
applied this test to 422 patients who presented with HD in Greater Manchester during 1962-8. Their findings were largely negative; but several pertinent issues were left unexplored, perhaps because of data limitations. Firstly, all pairs living less than $2 \mathrm{~km}$ apart were grouped together, so that any clustering below this limit could have been overlooked. Secondly, the distribution between successive time intervals exhibited by pairs close in space was not examined for evidence of a constant incubation period. Thirdly, the data were not analysed by histological subtype, although one of these subtypes, nodular sclerosis, has clinical and epidemiological features which suggest that it could differ in aetiology from the remainder. We describe a study of a larger Greater Manchester series in which all these issues were explored. A more detailed account of the findings is given by Mangoud. ${ }^{11}$

\section{Material}

The data base for this study includes all the 924 cases of HD registered by the North Western Regional Cancer Registry for the years 1962-76 in residents of that part of Greater Manchester which was formerly known as the South-East Lancashire Conurbation. The distribution of these cases by sex, age, and histological subtype is shown in table 1 . The information on subtypes was obtained by direct enquiry from hospital pathologists but was not available for $48 \%$ of the cases. In general, these frequencies are typical of those exhibited by HD in most affluent western countries-where incidence among men is greater than among women and where a peak in early adult life is followed by a gradual increase in old age. ${ }^{12} 13$

\section{Methods}

The test proposed by $\mathrm{Knox}^{8}$ involves specifying each of the $N=n(n-1) / 2$ possible pairings of the $n$ cases and then assigning each pair to a contingency table categorised by intervals between dates of onset on one axis and distances between places of residence on the other. Significance tests for space-time clustering are made on the differences between the observed cell frequencies and the expected frequencies obtained when the product of the marginal row and column frequencies is divided by $N$. The sampling theory for such tests depends largely on the work of David and Barton, ${ }^{14}$ who, by theoretical and simulation studies, showed that in a large sample the expected distribution of pairs close in both space and time follows the Poisson distribution. This finding is conditional upon the number of pairs defined as near in space and time being substantially smaller than the
Table 1 Frequency of Hodgkin's disease in Greater Manchester, 1962-76

\begin{tabular}{lcll}
\hline & Number & $\begin{array}{l}\text { Related } \\
\text { population } \\
\text { (millions) }\end{array}$ & $\begin{array}{l}\text { Annual } \\
\text { incidence } \\
\text { (per million) }\end{array}$ \\
\hline Total & 924 & $2 \cdot 4169$ & 26 \\
Male & 578 & $1 \cdot 1651$ & 33 \\
Female & 346 & $1 \cdot 2508$ & 19 \\
Aged <15 years & 39 & .5820 & 4 \\
$\quad$ 15-44 years & 418 & .9311 & 30 \\
$\quad$ 245 years & 467 & .9038 & 35 \\
Lymphocyte predominance & 111 & $2 \cdot 4169$ & 3 \\
Mixed cellularity & 211 & $-2 \cdot 4169$ & 6 \\
$\begin{array}{l}\text { Lymphocyte depletion } \\
\text { Nodular sclerosis }\end{array}$ & 85 & $2 \cdot 4169$ & 2 \\
Unclassified & 73 & 2.4169 & 2 \\
\hline
\end{tabular}

"Estimated from the Registrar General's Statistical Review of England and Wales for the years 1964,1969 , and 1973.

number of remaining pairs. For this reason, significance tests for space-time interaction are made on a collapsed $2 \times 2$ version of the original table and consist of a one-tailed evaluation of the null hypothesis of no significant difference between the observed frequency in the specified cell and its expected frequency.

In the present study, the Poisson distribution was used for this evaluation when the expected frequency was $<5$ and the $\chi^{2}$ distribution otherwise. Date of first hospital attendance and place of residence at this time were used as surrogates for date and place of onset, place being defined by pairs of Ordnance Survey grid codes accurate to $0.1 \mathrm{~km}$. Significant clustering was first sought among the whole set of $n=922^{*}$ cases and then among subsets of the population defined by age, sex, or histology.

\section{Results}

\section{ALL CASES}

Initially our analysis of space-time interactions was based upon contingency tables where pairs were assigned to classes of time and distance defined by the upper bounds $30,60,120,240,360,720,1080$, $1440,1800,2160$, and 2520 days for time, and 0.5 , $1 \cdot 0,2 \cdot 0,4 \cdot 0,8 \cdot 0$, and $16 \cdot 0 \mathrm{~km}$ for distance. However, virtually all the significant findings involved pairs whose members were less than 720 days and $2 \mathrm{~km}$ apart. There was no clear tendency for cases that were close in space and not in time to be separated by time intervals of a particular length, as might be expected if HD was a transmissible disease with a fixed incubation period. For these reasons,

* Places of residence could not be identified for two of the full set of $n=924$ registered cases. 
only the cumulative frequencies of pairs of cases less than 721 days and $2 \mathrm{~km}$ apart are tabulated here. So few significant results occurred beyond these bounds that their omission may be justified as an attempt to minimise the risk of committing type I errors.

The contingency table for all pairs of cases within the above bounds (table 2) shows that a majority of the cells bounded by intervals of less than 361 days and distances of less than $1 \mathrm{~km}$ contained excesses of pairs that were significant at the $p \leqslant 0.05$ level.

\section{DISAGGREGATION BY SEX}

The variable incidence of HD by both sex and age suggests that the disease may not be a homogeneous malignant entity, in which case different groups within the population may well be characterised by different patterns of space-time interaction. Analysing the sexes separately (table 3 ) produced a pattern like that found among all patients. Nearly all the significant differences occur in cells representing pairs of patients less than one year and $1 \mathrm{~km}$ apart. The clustering is more pronounced among females, in terms of both the number of significant differences within cells ( 7 significant female clusters against 2 male) and the magnitude of these differences.

DISAGGREGATION BY AGE

Analysing the data by age of patient (table 4) produced a more varied pattern of clustering than the sex categorisation. For the $0-14$ year old age group

Table 2 Space-time table for 'close pairs' among all cases of HD

\begin{tabular}{|c|c|c|c|c|c|c|c|}
\hline \multirow{3}{*}{$\begin{array}{l}\text { Time apart } \\
\text { (days) }\end{array}$} & \multicolumn{6}{|c|}{ Distance apart } & \multirow{3}{*}{$\begin{array}{l}\text { All } \\
\text { pairs }\end{array}$} \\
\hline & \multicolumn{2}{|c|}{$<0.5 \mathrm{~km}$} & \multicolumn{2}{|l|}{$<1 \mathrm{~km}$} & \multicolumn{2}{|l|}{$<2 \mathrm{~km}$} & \\
\hline & $O$ & $E$ & $O$ & $E$ & $O$ & $E$ & \\
\hline$\leqslant 30$ & $15^{*}$ & 8.7 & 38 & $29 \cdot 3$ & 113 & $97 \cdot 7$ & 4707 \\
\hline$\leqslant 60$ & $26^{*}$ & $17 \cdot 1$ & $70^{*}$ & $57 \cdot 4$ & 206 & 191.4 & 9224 \\
\hline$\leqslant 120$ & $46^{*}$ & $34 \cdot 4$ & 133 & 115.6 & $420^{*}$ & $385 \cdot 6$ & 18583 \\
\hline$\leqslant 240$ & $90 \div$ & $67 \cdot 6$ & $260^{*}$ & $227 \cdot 3$ & 795 & $758 \cdot 4$ & 36544 \\
\hline$\leqslant 360$ & $122^{*}$ & $100 \cdot 0$ & $372^{*}$ & $336 \cdot 6$ & 1171 & 1123.0 & 54113 \\
\hline$\leqslant 720$ & 207 & 193.8 & 689 & $652 \cdot 0$ & 2220 & $2175 \cdot 1$ & 104813 \\
\hline All pairs & 785 & & 2641 & & 8811 & & 424581 \\
\hline
\end{tabular}

Table 3 Space-time table for 'close pairs' of cases disaggregated by sex

\begin{tabular}{|c|c|c|c|c|c|c|c|c|}
\hline \multirow{3}{*}{\multicolumn{2}{|c|}{$\begin{array}{l}\text { Time apart } \\
\text { (days) }\end{array}$}} & \multicolumn{6}{|c|}{ Distance apart } & \multirow{3}{*}{$\begin{array}{l}\text { All } \\
\text { pairs }\end{array}$} \\
\hline & & \multicolumn{2}{|c|}{$<0.5 \mathrm{~km}$} & \multicolumn{2}{|l|}{$<1 \mathrm{~km}$} & \multicolumn{2}{|c|}{$<2 \mathrm{~km}$} & \\
\hline & & $O$ & $E$ & $O$ & $E$ & $O$ & $E$ & \\
\hline$\leqslant 30$ & $\begin{array}{l}\mathbf{M} \\
\mathbf{F}\end{array}$ & $\begin{array}{l}5 \\
5+\end{array}$ & $\begin{array}{l}3 \cdot 2 \\
1 \cdot 3\end{array}$ & $\begin{array}{c}12 \\
9^{*}\end{array}$ & $\begin{array}{r}11 \cdot 0 \\
4 \cdot 7\end{array}$ & $\begin{array}{l}41 \\
17\end{array}$ & $\begin{array}{l}37 \cdot 2 \\
14 \cdot 7\end{array}$ & $\begin{array}{r}1803 \\
667\end{array}$ \\
\hline$\leqslant 60$ & $\begin{array}{l}\mathbf{M} \\
\mathbf{F}\end{array}$ & $\begin{array}{r}11^{*} \\
7 \div\end{array}$ & $\begin{array}{l}6 \cdot 3 \\
2 \cdot 6\end{array}$ & $\begin{array}{l}29 \\
14\end{array}$ & $\begin{array}{r}22 \cdot 0 \\
9 \cdot 1\end{array}$ & $\begin{array}{l}78 \\
29\end{array}$ & $\begin{array}{l}74 \cdot 3 \\
28 \cdot 1\end{array}$ & $\begin{array}{l}3597 \\
1274\end{array}$ \\
\hline$\leqslant 120$ & $\begin{array}{l}\mathbf{M} \\
\mathbf{F}\end{array}$ & $\begin{array}{l}18 \\
10^{*}\end{array}$ & $\begin{array}{r}12.9 \\
5 \cdot 2\end{array}$ & $\begin{array}{l}56^{*} \\
24\end{array}$ & $\begin{array}{l}44 \cdot 6 \\
18 \cdot 3\end{array}$ & $\begin{array}{r}170 \\
56\end{array}$ & $\begin{array}{r}150 \cdot 6 \\
56 \cdot 5\end{array}$ & $\begin{array}{l}7291 \\
2567\end{array}$ \\
\hline$\leqslant 240$ & $\begin{array}{l}\mathbf{M} \\
\mathbf{F}\end{array}$ & $\begin{array}{l}32 \\
20\end{array}$ & $\begin{array}{l}25 \cdot 3 \\
10 \cdot 2\end{array}$ & $\begin{array}{l}93 \\
47^{*}\end{array}$ & $\begin{array}{l}87 \cdot 7 \\
36 \cdot 0\end{array}$ & $\begin{array}{l}304 \\
118\end{array}$ & $\begin{array}{l}296 \cdot 2 \\
111 \cdot 5\end{array}$ & $\begin{array}{r}14340 \\
5063\end{array}$ \\
\hline$\leqslant 360$ & $\begin{array}{l}\mathbf{M} \\
\mathbf{F}\end{array}$ & $\begin{array}{l}45 \\
25\end{array}$ & $\begin{array}{l}37 \cdot 5 \\
15 \cdot 0\end{array}$ & $\begin{array}{r}142 \\
62\end{array}$ & $\begin{array}{r}130.2 \\
52.9\end{array}$ & $\begin{array}{l}454 \\
171\end{array}$ & $\begin{array}{l}439.6 \\
163.6\end{array}$ & $\begin{array}{r}21287 \\
7431\end{array}$ \\
\hline$\leqslant 720$ & $\begin{array}{l}\mathbf{M} \\
\mathbf{F}\end{array}$ & $\begin{array}{l}74 \\
37\end{array}$ & $\begin{array}{l}72 \cdot 7 \\
29 \cdot 2\end{array}$ & $\begin{array}{l}248 \\
110\end{array}$ & $\begin{array}{l}252 \cdot 3 \\
103 \cdot 0\end{array}$ & $\begin{array}{l}848 \\
314\end{array}$ & $\begin{array}{l}851 \cdot 8 \\
318 \cdot 7\end{array}$ & $\begin{array}{l}41242 \\
14472\end{array}$ \\
\hline All pairs & $\begin{array}{l}\mathbf{M} \\
\mathbf{F}\end{array}$ & $\begin{array}{l}294 \\
119\end{array}$ & & $\begin{array}{r}1020 \\
420\end{array}$ & & $\begin{array}{l}3444 \\
1299\end{array}$ & & $\begin{array}{r}166753 \\
58996\end{array}$ \\
\hline \multicolumn{9}{|c|}{$\begin{array}{l}M=\text { Males } \\
F=\text { Females } \\
* \text { Difference significant at the } p \leqslant 0.05 \text { level } \\
\div \text { Difference significant at the } p \leqslant 0.01 \text { level }\end{array}$} \\
\hline
\end{tabular}


all the cells representing time intervals of less than 721 days and distances less than $1 \mathrm{~km}$ show statistically significant differences. However, the importance attached to these results must be tempered by the knowledge that there were only 39 patients in this age group. Consequently the expected frequencies are often close to zero, and significant differences can be obtained from a relatively small number of observed pairings.

Statistically significant clustering was not seen in the 15-44 year old group, but positive results re-emerged in the over 45 year old group, with the same spatial limit $(<1 \mathrm{~km})$ as in the youngest age group but a more restricted temporal limit $(\leqslant 120$ days).

\section{DISAGGREGATION BY AGE AND SEX}

An economical summary of the results obtained when the data are broken down by age and sex simultaneously is given in table 5. Here attention is focussed on pairs with members less than 241 days and $0.5 \mathrm{~km}$ apart, which produced the most significant result $(p \leqslant 0.005)$ in the analysis of all cases (table 2). The right hand column of table 5 gives a breakdown of pairs by age within this space-time class and shows that significant contributions to the overall excess were made by pairs of children, by pairs of patients over 45 , and by pairs with members from two age groups. Further analysis (not shown) revealed that only adult patients were involved in the excess pairs of mixed age group. The excess of child pairs involved only girls; but male, female, and mixed sex pairs all contributed to the excesses of pairs aged 45 plus and those of mixed age group.

The bottom row of table 5 reveals that only females contributed significantly to the excess of pairs for all ages combined. This female excess was produced mainly by pairs of children and pairs of mixed age. Most notably, the female children (who numbered only 14 in the entire series) yielded three close pairs. Further inspection of the registration records revealed that these pairs involved only three girls, who all lived within $150 \mathrm{~m}$ of each other on a housing estate between Manchester and Bury and who all attended hospital within 20 days of one another. All three were aged 10-12 years at the time of the first hospital attendance and subsequently died aged 14-16 years.

DISAGGREGATION BY HISTOLOGICAL SUBTYPES Analysis of the data by histological subtype (lymphocyte depletion, mixed cellularity, lymphocyte predominance, and nodular sclerosis-not shown) produced no significant levels

Table 4 Space-time table for 'close pairs' of cases disaggregated by age

\begin{tabular}{|c|c|c|c|c|c|c|c|c|}
\hline & & Distan & & & & & & \\
\hline & & $<0.5$ & & $<l k n$ & & $<2 \mathrm{~km}$ & & pairs \\
\hline (days) & & $O$ & $E$ & $O$ & $E$ & $O$ & $E$ & Totals \\
\hline$\leqslant 30$ & $\begin{array}{l}\text { A } \\
\text { B } \\
\text { C }\end{array}$ & $\begin{array}{l}3 \div \\
2 \\
4\end{array}$ & $\begin{array}{l}0 \cdot 1 \\
1 \cdot 9 \\
2 \cdot 2\end{array}$ & $\begin{array}{c}3 \div \\
5 \\
15 \div\end{array}$ & $\begin{array}{l}0 \cdot 1 \\
5 \cdot 9 \\
7 \cdot 7\end{array}$ & $\begin{array}{l}3 \div \\
20 \\
33\end{array}$ & $\begin{array}{r}0.3 \\
18.7 \\
26.4\end{array}$ & $\begin{array}{r}11 \\
981 \\
1192\end{array}$ \\
\hline$\leqslant 60$ & $\begin{array}{l}\text { A } \\
\text { B } \\
\text { C }\end{array}$ & $\begin{array}{l}3 \div \\
5 \\
5\end{array}$ & $\begin{array}{l}0 \cdot 2 \\
3 \cdot 7 \\
4 \cdot 2\end{array}$ & $\begin{array}{c}3 \div \\
11 \\
24 \div\end{array}$ & $\begin{array}{r}0 \cdot 3 \\
11 \cdot 5 \\
14 \cdot 8\end{array}$ & $\begin{array}{r}3 \\
34 \\
59\end{array}$ & $\begin{array}{r}0.7 \\
36.4 \\
50.8\end{array}$ & $\begin{array}{r}22 \\
1915 \\
2296\end{array}$ \\
\hline$\leqslant 120$ & $\begin{array}{l}\text { A } \\
\text { B } \\
\text { C }\end{array}$ & $\begin{array}{c}3 \div \\
5 \\
14^{*}\end{array}$ & $\begin{array}{l}0 \cdot 4 \\
7 \cdot 3 \\
8 \cdot 5\end{array}$ & $\begin{array}{l}3 \div \\
17 \\
43 \div\end{array}$ & $\begin{array}{r}0.5 \\
22.7 \\
30 \cdot 1\end{array}$ & $\begin{array}{r}3 \\
62 \\
120\end{array}$ & $\begin{array}{r}1 \cdot 2 \\
72 \cdot 2 \\
103.6\end{array}$ & $\begin{array}{r}39 \\
3793 \\
4679\end{array}$ \\
\hline$\leqslant 240$ & $\begin{array}{l}\text { A } \\
\text { B } \\
\text { C }\end{array}$ & $\begin{array}{l}3^{\dagger} \\
14 \\
24^{*}\end{array}$ & $\begin{array}{r}0 \cdot 5 \\
14 \cdot 3 \\
17 \cdot 1\end{array}$ & $\begin{array}{l}3^{*} \\
47 \\
70\end{array}$ & $\begin{array}{r}0.7 \\
44 \cdot 3 \\
60 \cdot 3\end{array}$ & $\begin{array}{r}3 \\
132 \\
219\end{array}$ & $\begin{array}{r}1.9 \\
140 \cdot 6 \\
207 \cdot 7\end{array}$ & $\begin{array}{r}61 \\
7390 \\
9381\end{array}$ \\
\hline$\leqslant 360$ & $\begin{array}{l}\text { A } \\
\text { B } \\
\text { C }\end{array}$ & $\begin{array}{l}4 广 \\
21 \\
29\end{array}$ & $\begin{array}{r}0 \cdot 8 \\
21 \cdot 2 \\
25 \cdot 3\end{array}$ & $\begin{array}{r}4^{*} \\
67 \\
103\end{array}$ & $\begin{array}{r}1 \cdot 1 \\
65 \cdot 7 \\
89 \cdot 3\end{array}$ & $\begin{array}{r}5 \\
204 \\
321\end{array}$ & $\begin{array}{r}2 \cdot 8 \\
208 \cdot 6 \\
307 \cdot 1\end{array}$ & $\begin{array}{cc} & 91 \\
10 & 963 \\
13 & 875\end{array}$ \\
\hline$\leqslant 720$ & $\begin{array}{l}\text { A } \\
\text { B } \\
\text { C }\end{array}$ & $\begin{array}{l}6 \div \\
47 \\
47\end{array}$ & $\begin{array}{r}1.6 \\
41.0 \\
49.0\end{array}$ & $\begin{array}{r}6^{*} \\
140 \\
190\end{array}$ & $\begin{array}{r}2 \cdot 1 \\
127 \cdot 0 \\
172 \cdot 7\end{array}$ & $\begin{array}{r}8 \\
392 \\
613\end{array}$ & $\begin{array}{r}5.6 \\
403 \cdot 0 \\
594 \cdot 3\end{array}$ & $\begin{array}{r}182 \\
21 \\
186 \\
26850\end{array}$ \\
\hline All pairs & $\begin{array}{l}\text { A } \\
\text { B } \\
\text { C }\end{array}$ & $\begin{array}{r}7 \\
168 \\
197\end{array}$ & & $\begin{array}{r}9 \\
520 \\
694\end{array}$ & & $\begin{array}{r}24 \\
1650 \\
2388\end{array}$ & & $\begin{array}{r}780 \\
86736 \\
107880\end{array}$ \\
\hline
\end{tabular}

$A=$ aged $0-14$ years.

$B=$ aged $15-44$ years.

$C=$ aged 45 years and over.

* Difference significant at the $p \leqslant 0.05$ level

$\leftarrow$ Difference significant at the $p \leqslant 0.01$ level 
Table 5 Age and sex characteristics of 'close pairs' of cases of HD separated by $\leqslant 240$ days and $<0.5 \mathrm{~km}$

\begin{tabular}{|c|c|c|c|c|c|c|c|c|}
\hline \multirow{2}{*}{$\begin{array}{l}\text { Characteristics } \\
\text { of pair members }\end{array}$} & \multicolumn{2}{|c|}{$\begin{array}{l}\text { Both } \\
\text { male }\end{array}$} & \multicolumn{2}{|c|}{$\begin{array}{l}\text { Both } \\
\text { female }\end{array}$} & \multicolumn{2}{|c|}{$\begin{array}{l}\text { One male } \\
\text { one female }\end{array}$} & \multicolumn{2}{|l|}{ Total } \\
\hline & $O$ & $E$ & $O$ & $\boldsymbol{E}$ & $o$ & $E$ & $O$ & $\boldsymbol{E}$ \\
\hline Both aged $<15$ & 0 & 0.2 & $3 \div$ & 0.3 & 0 & $0 \cdot 1$ & $3 \div$ & 0.6 \\
\hline Both aged 15-44 & 5 & 5.7 & 2 & 1.6 & 7 & 7.0 & 14 & $14 \cdot 3$ \\
\hline Both aged $\geqslant 45$ & 7 & 6.0 & 5 & $\mathbf{3} \cdot \mathbf{3}$ & 12 & 7.8 & $24^{*}$ & $17 \cdot 1$ \\
\hline One from each of two age groups & $20^{*}$ & 13.4 & $10^{*}$ & 5.0 & 19 & $17 \cdot 2$ & $49^{*}$ & 35.6 \\
\hline Total & 32 & $25 \cdot 3$ & $20 \div$ & $10 \cdot 2$ & 38 & $32 \cdot 1$ & $90^{\circ}$ & 67.6 \\
\hline
\end{tabular}

*Difference significant at the $p \leqslant 0.05$ level.

$\div$ Difference significant at the $p \leqslant 0.01$ level.

of clustering. However, such findings do not necessarily imply that histology can be dismissed as a source of clustering since only $52 \%$ of the cases could be accurately classified.

\section{Discussion}

The present study yielded no evidence of a definite incubation period or of clustering specific to a particular histological subtype of HD. However, in contrast to the results obtained by Alderson and Nayak $^{9}$ with part of the same data, an excess of pairs close in space and time was observed. This discrepancy between studies may be due to the fact that the earlier workers did not use any distance below $2 \mathrm{~km}$ as an upper limit of closeness.

If the reason for the excess of close pairs is that an infective process is involved in the aetiology of HD, it seems from the limits within which the excess occurred (table 2 ) that the infection may generally be acquired within $1 \mathrm{~km}$ of home and have an incubation period of less than one year. This conclusion is consistent with a recent 15-year series of Greater Boston cases in which rather more than expected were less than $0.5 \mathrm{~km}$ and six months apart ${ }^{15}$. However, the excess of close pairs in the Boston series was apparently confined to patients aged 45 or less, whereas the excess observed in the present study included a substantial contribution from patients over 45 years and therefore suggests that infection is at least as likely to be related to disease in the old as in the young.

One limitation of the above approach to space-time analysis is that it does not distinguish between excess pairs that are concentrated in the same locality (as the female child pairs were) and excess pairs that are scattered throughout the study area. Clearly, further work is needed to establish whether the excesses of close pairs observed in adults occur in particular localities.

We are grateful to Professor E G Knox and Professor Alwyn Smith for much useful advice; to the staff of the Department of Epidemiology and Social Research, University Hospital of South Manchester, especially Ms Frances Kelly, for invaluable assistance with assembling and processing our data; and to the North Western Regional Health Authority for financial support.

\section{References}

${ }^{1}$ Vianna NJ, Greenwald P, Brady J, Polan AK, Dwork A, Mauro J, Davies JNP. Hodgkin's Disease: cases with $\bigcirc$ features of a community disease. Ann Internal Med 1972; 77: 169-80.

${ }^{2}$ Vianna NJ, Polan AK. (1973) Epidemiologic evidence for transmission of Hodgkin's Disease. New Engl J Med 1973; 289: 499-502.

${ }^{3}$ Dworsky RL, Henderson BE. Hodgkin's Disease clustering in families and communities. Cancer Resce 1974; 34: 1161-3.

${ }^{4}$ Smith PG, Pike MC. Case clustering in Hodgkin's Disease: a brief review of the present position and report of current work in Oxford. Cancer Res 1974; 34: 1156-60.

${ }^{5}$ Smith PG, Pike MC, Kinlen LJ, Jones A, Harris R. Contacts between young patients with Hodgkin's Disease. A case-control study. Lancet 1977; ii: 59-62.

'Abramson JH, Goldblum N, Avitzur M, Priden H, Sacks MI, Peritz E. Clustering of HD in Israel: a case control study. Internat J Epidemiol 1980; 9: 137-44.

${ }^{7}$ Editorial (1981). Advance and retreat in Hodgkin's disease. Lancet 1981; i: 924-5.

${ }^{8} \mathrm{Knox}$ EG. The detection of space-time interactions. Appl Statis 1964; 13: 25-30.

${ }^{9}$ Alderson MR, Nayak R. A study of space-time clustering in $\mathrm{HD}$ in the Manchester region. Br J Prev Soc Med 1971; 25: 168-73.

${ }^{10}$ Alderson MR, Nayak R. Epidemiology of Hodgkin's Disease. J Chron Dis 1972; 25: 253-9.

${ }^{11}$ Mangoud AMM. Tests of the transmissibility hypothesis of Hodgkin's Disease. PhD thesis, University of Manchester, 1981.

${ }^{12}$ MacMahon B. Epidemiological evidence on the nature of Hodgkin's Disease. Cancer 1957; 10: 1045-54.

${ }^{13}$ MacMahon B. Epidemiology of Hodgkin's Disease. Cancer Res 1966; 26: 1189-200.

${ }^{14}$ David FN, Barton DE. Two space-time interaction tests for epidemicity. Br J Prev Soc Med 1966; 20: 44-8.

${ }^{15}$ Greenberg RS, Grufferman S, and Cole P. An evaluation of space-time clustering in Hodgkin's disease. Journal of Chronic Diseases 1983; 36: 257-62. 